\title{
Reported Benefits of Low-Dose Naltrexone Appear to Be Independent of the Endogenous Opioid System Involving Proopiomelanocortin Neurons and $\beta$-Endorphin
}

\author{
Marissa J. Metz, Caitlin M. Daimon, and ĐShane T. Hentges
}

https://doi.org/10.1523/ENEURO.0087-21.2021

Department of Biomedical Sciences and Program in Molecular, Cellular, and Integrative Neurosciences, Colorado State University, Fort Collins, CO 80523

\begin{abstract}
Naltrexone is an opioid receptor antagonist approved for the treatment of alcohol and opioid use disorders at doses of $50-150 \mathrm{mg} / \mathrm{d}$. Naltrexone has also been prescribed at much lower doses $(3-6 \mathrm{mg} / \mathrm{d})$ for the off-label treatment of inflammation and pain. Currently, a compelling mechanistic explanation for the reported efficacy of low-dose naltrexone (LDN) is lacking and none of the proposed mechanisms can explain patient reports of improved mood and sense of well-being. Here, we examined the possibility that LDN might alter the activity of the endogenous opioid system involving proopiomelanocortin (POMC) neurons in the arcuate nucleus of the hypothalamus (ARH) in male and female mice. Known actions of POMC neurons could account for changes in pain perception and mood. However, using electrophysiologic, imaging and peptide measurement approaches, we found no evidence for such a mechanism. LDN did not change the sensitivity of opioid receptors regulating POMC neurons, the production of the $\beta$-endorphin precursor Pomc mRNA, nor the release of $\beta$-endorphin into plasma. Spontaneous postsynaptic currents (sPSCs) onto POMC neurons were slightly decreased after LDN treatment and GCaMP fluorescent signal, a proxy for intracellular calcium levels, was slightly increased. However, LDN treatment did not appear to change POMC neuron firing rate, resting membrane potential, nor action potential threshold. Therefore, LDN appears to have only slight effects on POMC neurons that do not translate to changes in intrinsic excitability or baseline electrical activity and mechanisms beyond POMC neurons and altered opioid receptor sensitivity should continue to be explored.
\end{abstract}

Key words: $\beta$-endorphin; hypothalamus; naltrexone; opioid receptor; POMC

\section{Significance Statement}

Naltrexone blocks opioid receptor activity and is used for the treatment of alcohol and opioid use disorders but is also prescribed at lower doses to treat inflammation and pain. A compelling mechanistic explanation for the reported efficacy of low-dose naltrexone (LDN) is lacking, and understanding the central effects of LDN is important, both for basic science and to inform future applications of LDN for central disorders. We hypothesized that LDN might alter the activity of endogenous opioid systems in proopiomelanocortin (POMC) neurons of the hypothalamus. However, we found no evidence for such a mechanism and LDN appears to only slightly affect POMC neurons. We conclude that future studies should shift focus to other opioid systems outside of POMC neurons.

Received March 6, 2021; accepted May 14, 2021; First published May 24, 2021.

The authors declare no competing financial interests.
Author contributions: S.T.H. and M.J.M. designed research; M.J.M. and C.M.D. performed research; M.J.M. and C.M.D. analyzed data; S.T.H. and M.J.M. wrote the paper. 


\section{Introduction}

Naltrexone is an antagonist of opioid receptors that has high binding affinity for the $\mu$-opioid receptor (MOR), although it also binds $\delta$ - and $\kappa$-opioid receptors (Raynor et al., 1994). Naltrexone was approved for use at doses of $50-150 \mathrm{mg}$ to lessen relapse to alcohol and opioid use, which is efficacious largely because of blocking the rewarding actions of these drugs heavily mediated through MORs (Gold et al., 1982; Matthes et al., 1996). In addition to use in treatment for substance use disorders, naltrexone has been prescribed at a much lower dose (3-6 mg) for off-label use in immune-related pain disorders and cancer (Toljan and Vrooman, 2018; Trofimovitch and Baumrucker, 2019). The reported efficacy for low-dose naltrexone (LDN) is paradoxical; MOR agonists, not antagonists, convey analgesic and rewarding properties that can be blocked by application of antagonists. Nonetheless, many anecdotal reports (Ramanathan et al., 2012; Chopra and Cooper, 2013; Ghai et al., 2014; Leonard et al., 2017; Bolton et al., 2020; Zappaterra et al., 2020), post hoc studies (Ludwig et al., 2016; Raknes and Småbrekke, 2017, 2019; Raknes et al., 2018), and limited clinical trials (Younger and Mackey, 2009; Younger et al., 2013; Brewer et al., 2018; Lie et al., 2018) suggest that LDN may be useful for treating chronic pain and inflammation. Further, in many of these studies patients report effects such as improved feelings of well-being and vivid dreams (Younger and Mackey, 2009; Younger et al., 2013; Brewer et al., 2018; Lie et al., 2018; Bolton et al., 2020; Zappaterra et al., 2020), and recently LDN has been tested as an adjunct therapy for patients living with depression (Mischoulon et al., 2017) with some promising preliminary results. In the context of naltrexone's antagonist functions, these benefits are also surprising, as opioid receptor agonism typically induces feelings of euphoria and well-being.

To date, the beneficial effects of LDN have been primarily attributed to inhibition of peripheral inflammatory responses mediated through the Toll-like receptor 4, although a mechanism whereby ultra-LDN $(<1 \mu \mathrm{g} / \mathrm{d})$ acts on a MOR scaffolding protein, filamin $A$, has also been proposed (Wang and Burns, 2009; Burns and Wang, 2010). Patients receiving LDN often report subjective benefits in the absence of clear objective measures indicative of improvement (Patten et al., 2018). It may be that unrecognized or underappreciated central actions of LDN underpin these anecdotal reports of "feeling better." Studies from decades ago indicated that LDN could decrease tumor growth in mice, and the authors suggested

This work was supported by the National Science Foundation Grant DGE1321845 (to M.J.M.) and the National Institutes of Health Grant R01DA032562 (to S.T.H.).

Acknowledgements: We thank Connie King for excellent technical assistance and colony maintenance and Chrystina Crown for performing injections.

Correspondence should be addressed to Shane T. Hentges at shane. hentges@colostate.edu.

https://doi.org/10.1523/ENEURO.0087-21.2021

Copyright (C) 2021 Metz et al.

This is an open-access article distributed under the terms of the Creative Commons Attribution 4.0 International license, which permits unrestricted use, distribution and reproduction in any medium provided that the original work is properly attributed. a mechanism whereby LDN causes a resetting of the endogenous opioid system that allows for a period of rest and re-sensitization of receptors as well as a refilling of endogenous opioid stores to allow the system to function optimally (Zagon and McLaughlin, 1983). Here, we hypothesized that such a mechanism could underlie the positive effects of LDN on subjective affect.

The central $\beta$-endorphin system is a key endogenous opioid system within the brain, and knock-out of $\beta$-endorphin causes deficits in reward-related behaviors (Hayward et al., 2002) and analgesia (Parikh et al., 2011; Labuz et al., 2016). $\beta$-Endorphin is produced in the brain from the precursor peptide proopiomelanocortin (POMC), primarily in neurons in the arcuate nucleus of the hypothalamus (ARH; Veening et al., 2012). Further, POMC neurons of the $\mathrm{ARH}$ are heavily regulated both presynaptically and postsynaptically by MORs (Pennock and Hentges, 2011; Fox and Hentges, 2017). Because most of the neurons in the brain that produce $\beta$-endorphin are in the $\mathrm{ARH}$, we hypothesized that LDN may exert effects directly on MORs affecting ARH POMC neuron activity and alter the production and release of $\beta$-endorphin to partially explain the centrally-mediated actions of LDN.

\section{Materials and Methods}

\section{Animals}

Mice were maintained with approval by the Animal Care and Use Committee of Colorado State University and in accordance with the Guide for the Care and Use of Laboratory Animals (Council, 2011). Mice backcrossed to the C57BL/6 strain (The Jackson Laboratory), were group-housed under a 12/12 h light/dark cycle [zeitgeber time $(Z T) 0=6$ A.M.] and given ad libitum access to food and water. Male and female mice were used for all experiments, and all mice were between 8 and 12 weeks of age at the time of tissue collection. Transgenic mice expressing Discosoma red (Pomc-DsRed, gifted by Malcolm Low, University of Michigan) or enhanced green fluorescent protein (Pomc-eGFP, Jax stock \#009593) under the control of the Pomc promoter were used to identify POMC cells during electrophysiological recordings. Mice expressing CRE recombinase driven by the Pomc promoter (Pomc $^{\mathrm{Cre} /+}$; The Jackson Laboratory, stock \#005965) mice were used for stereotaxic injection of the AAVGCaMP6f vector and subsequent GCaMP fluorescence imaging experiments.

\section{LDN treatment}

Naltrexone was dissolved in sterile saline to a concentration of $0.025 \mathrm{mg} / \mathrm{ml}$ to make LDN and was stored at $-20^{\circ} \mathrm{C}$ for no more than $7 \mathrm{~d}$. Mice were injected intraperitoneally with $0.1 \mathrm{mg} / \mathrm{kg}$ LDN between 7 and 8 A.M. and returned to their home cage. On day 3,7 , or 12 , mice were euthanized $2 \mathrm{~h}$ after the final injection, when brain naltrexone concentrations will have fallen to, at most, $2-3 \%$ of peak (Misra et al., 1976).

\section{Stereotaxic microinjection}

For stereotaxic microinjections, Pomc $\mathrm{Cre}^{\mathrm{C}+}$ animals were first deeply anesthetized with $5 \%$ isofluorane and 
then anesthesia was maintained with $2 \%$ isofluorane. Hair was removed and skin was cleaned for surgery before animals were placed in a stereotaxic headframe (David Kopf Instruments) on top of a heating pad. A small hole was drilled into the skull, and a Neurosyringe ( $2 \mu$ l; Hamilton) was lowered into place at $1 \mathrm{~mm} / \mathrm{s}$ into the ARH (from bregma, A/P: -1.63 , M/L: \pm 0.32 , D/V: -6.00 ). A doublefloxed AAVGCaMP6f (AAV9.CAG.Flex.GCaMP6f.WRPE. SV40; Penn Vector Core, University of Pennsylvania School of Medicine, Philadelphia, PA) was injected at 100 $\mathrm{nl} / \mathrm{min}$ for a total of $200 \mathrm{nl}$. The needle was left in place postinjection for $10 \mathrm{~min}$ and then raised at $1 \mathrm{~mm} / \mathrm{min}$. This process was repeated to achieve bilateral injection. During recovery, animals were maintained on a heating pad for at least $1 \mathrm{~h}$ and $5 \mathrm{mg} / \mathrm{kg}$ carprofen (Rimadyl, Pfizer) was administered daily for $3 \mathrm{~d}$ following surgery. LDN injections commenced on day 4 postsurgery and continued for $7 \mathrm{~d}$ before GCaMP imaging was performed.

\section{Patch clamp electrophysiology}

On the day of recording between 9 and 9:45 A.M., mice were deeply anesthetized with isoflurane and brains were immediately collected into ice-cold artificial CSF (aCSF; $126 \mathrm{~mm} \mathrm{NaCl}, 2.5 \mathrm{~mm} \mathrm{KCl}, 1.2 \mathrm{~mm} \mathrm{MgCl}_{2} \bullet 6 \mathrm{H} 2 \mathrm{O}, 2.4 \mathrm{~mm}$ $\mathrm{CaCl}_{2} \bullet 2 \mathrm{H} 2 \mathrm{O}, 1.2 \mathrm{~mm} \mathrm{NaH}{ }_{2} \mathrm{PO}_{4}, 11.1 \mathrm{~mm}$ glucose, and $21.4 \mathrm{mM} \mathrm{NaHCO}_{3}$ ) buffered with $95 \% \mathrm{O}_{2}$ and $5 \% \mathrm{CO}_{2}$ (carboxygen). Brains were transferred to a Leica VT1200S vibratome also containing ice-cold carboxygen-buffered aCSF and sliced $240 \mu \mathrm{m}$ thick in the region of the ARH. Slices were then transferred to aCSF kept at $37^{\circ} \mathrm{C}$ in a water bath. Slices were allowed to rest for at least $1 \mathrm{~h}$ before recording.

For recording, slices were maintained in a chamber constantly perfused with carboxygen-infused aCSF kept at $37^{\circ} \mathrm{C}$ via an in-line temperature controller. For current clamp experiments and experiments isolating spontaneous IPSCs (sIPSCs), MK 801 (15 $\mu \mathrm{M})$ was added to the bath solution to block NMDA receptors. POMC cells were identified by the presence of the eGFP or dsred reporter visualized through a $40 \times$ water-immersion objective (Olympus). Glass patch-pipets were pulled with a Narishige PC-10 vertical pipette puller (Narishige International) to a resistance between 1.4-2.0 $\mathrm{m} \Omega$ when filled with potassium methyl-sulfate/potassium chloride recording solution $(57.5 \mathrm{~mm} \mathrm{KCl}$, $57.5 \mathrm{~mm} \mathrm{CH}_{3} \mathrm{KO}_{4} \mathrm{~S}, 20 \mathrm{~mm} \mathrm{NaCl}, 1.5 \mathrm{~mm} \mathrm{MgCl}_{2}, 5 \mathrm{~mm}$ HEPES potassium salt, $0.1 \mathrm{~mm}$ EGTA, $2 \mathrm{~mm}$ ATP, $0.5 \mathrm{~mm}$ GTP, and $10 \mathrm{~mm}$ phosphocreatine; $\mathrm{pH}$ 7.3) for voltage clamp experiments or potassium gluconate recording solution (110 mm K-gluconate, $10 \mathrm{~mm} \mathrm{KCl,} 15 \mathrm{~mm} \mathrm{NaCl}, 1.5 \mathrm{~mm}$ $\mathrm{MgCl}_{2}, 10 \mathrm{~mm}$ HEPES-potassium salt, $1 \mathrm{~mm}$ EGTA, $2 \mathrm{~mm}$ $\mathrm{Mg}$-ATP, and 0.2 mM Na-GTP) for current clamp experiments, made fresh weekly and stored at $-20^{\circ} \mathrm{C}$. An AxoPatch 200B amplifier (Molecular Devices) was used to maintain membrane potential at $-60 \mathrm{mV}$. Test pulses of $10 \mathrm{pA}$ were used to ensure that cells were maintained with a series resistance no greater than $20 \mathrm{~m} \Omega$, and that the series resistance did not deviate by $>5 \mathrm{~m} \Omega$ from the original measured value on break in. Recordings were collected via AxoGraph software at $10 \mathrm{kHz}$ and filtered at $5 \mathrm{kHz}$. [Met5]enkephalin (ME; Sigma M6638) was prepared as a $10 \mathrm{~mm}$ solution in sterile water and kept at $4^{\circ} \mathrm{C}$ for no more than one month. Before adding to slices, ME was diluted in aCSF, buffered with carboxygen, and passively perfused over the slice during recording. A similar paradigm was followed for preparing drugs for experiments isolating sIPSCs and SEPSCs, where $10 \mu \mathrm{m}$ of the competitive AMPA antagonist DNQX (Sigma) was perfused onto the slice to isolate sIPSCs, or $10 \mu \mathrm{m}$ of the $\mathrm{GABA}_{\mathrm{A}}$ antagonist Bicuculline methiodide (Tocris) was perfused to isolate sEPSCs.

To analyze spontaneous activity, a model sPSC was created from an averaged sample of recordings via Axograph and used as a template for detection. Potassium currents were measured by sampling an average current before ME application and subtracting this value from the peak current measured $2-4$ min after drug application.

For action potential threshold experiments, a $>1-G \Omega$ seal was obtained in voltage clamp mode and the holding voltage brought to $-60 \mathrm{mV}$. Upon break-in, the AxoPatch 200B amplifier was quickly switched to current clamp mode $(I=0)$ and the membrane potential recorded. DNQX $(10 \mu \mathrm{M})$ and Bicuculline $(10 \mu \mathrm{M})$ were washed onto the slice before and during the experiment to block AMPAmediated and $\mathrm{GABA}_{\mathrm{A}}$-mediated currents. After at least 3 $\mathrm{m}$ of exposure to these blockers, the cell was current clamped to a membrane potential of $-60 \mathrm{mV}$, and a current ramp of 0-110 pA was applied three separate times.

\section{GCaMP imaging as an indicator of intracellular calcium levels}

For GCaMP fluorescence monitoring, slices were maintained as described above. GCaMP6f was visualized using a 470-nm LED (ThorLabs) and a $40 \times$ water immersion objective (Olympus). Slices were allowed to sit for $10 \mathrm{~min}$ in the recording chamber before allow the GCaMP6f fluorescence to stabilize in the condition. GCaMP fluorescence was then recorded using CellSens Dimension software (Olympus) at $10 \mathrm{~Hz}$ with a $50 \mathrm{~ms}$ exposure using an electron-multiplying chargecoupled device (Evolve $512 \delta$, Photometrics) for $10 \mathrm{~min}$ of baseline activity. After $10 \mathrm{~min}, 10 \mu \mathrm{M}$ ME was washed onto the slice as recording continued. To analyze baseline GCaMP6f fluorescence, all traces were normalized in Axograph to the reduced level of signal occurring in response to the ME application which significantly decreases calcium influx. These normalized traces were transferred to Prism (version 8) software for area under the curve analysis.

\section{Perfusion and fluorescent in situ hybridization (FISH)}

Mice were first deeply anesthetized with sodium pentobarbitol. Transcardial perfusion was then commenced first with $10 \%$ sucrose followed by $4 \%$ paraformaldehyde, both diluted in potassium phosphate buffer. Brains were extracted into $4 \%$ paraformaldehyde solution and stored overnight at $4^{\circ} \mathrm{C}$.

On day 1 of $\mathrm{FISH}$, the ARH was collected on ice in $50-\mu \mathrm{m}$ slices using a Leica VT100S vibratome. Slices were incubated at room temperature in $6 \% \mathrm{H} 2 \mathrm{O} 2$ for 
A
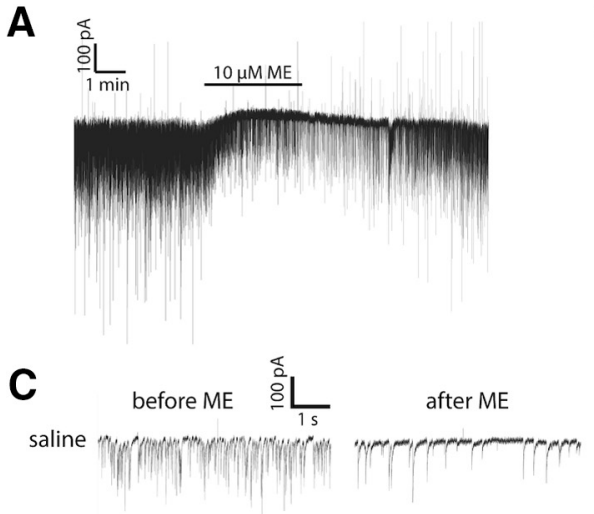

B

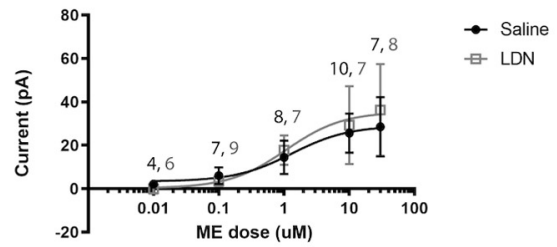

D

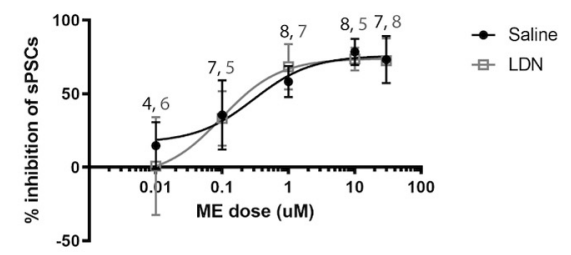

Figure 1. Treatment with LDN did not alter dose responses of opioid receptors on POMC neurons or on neurons presynaptic to POMC neurons. A, Example outward currents elicited by ME application $(10 \mu \mathrm{M})$. B. Dose-response curves for outward current generated by application of ME. No significant difference was found between dose-response curves. C, Example sPSCs recorded before and after ME application for saline and LDN injected groups. $\boldsymbol{D}$, Dose-response curves generated from the inhibition of spontaneous events after ME application compared with before ME application in saline and LDN groups. No significant difference was found between dose-response curves. Numbers in black $=\mathrm{n}$ for saline and numbers in gray $=\mathrm{n}$ for $\mathrm{LDN}$ represent the number of cells recorded from for each condition. Slice numbers are the same as cell numbers. Total mice for all dose responses: saline =21, LDN=19.

$15 \mathrm{~min}$ to quench endogenous peroxidase activity and then incubated for $15 \mathrm{~min}$ in proteinase $\mathrm{K}(10 \mu \mathrm{g} / \mathrm{ml})$ diluted in PBS containing $0.1 \%$ Tween 20 (PBT). Proteinase $\mathrm{K}$ was deactivated with incubation in $2 \mathrm{mg} / \mathrm{ml}$ glycine in PBT for 10 min. Following two 5-min washes in PBT, tissue was postfixed for $20 \mathrm{~min}$ in solution containing $4 \%$ paraformaldehyde and $0.2 \%$ gluteraldehyde. Tissue was washed once more in PBT, then dehydrated in ascending concentrations of $\mathrm{EtOH}$ diluted in DEPC-treated water $(50 \%, 70 \%, 95 \%$, and $100 \%)$ and then briefly rehydrated in PBT. Slices were transferred to vials and prehybridized in $66 \%$ deionized formamide, $13 \%$ dextran sulfate, 260 $\mathrm{mm} \mathrm{NaCl}, 1.3 \times$ Denhardt's solution, $13 \mathrm{~mm}$ Tris- $\mathrm{HCl}(\mathrm{pH}$ 8.0), and $1.3 \mathrm{~mm}$ EDTA (pH 8.0) for $1 \mathrm{~h}$ at $60^{\circ} \mathrm{C}$. Fluorescein isothiocyanate (FITC)-labeled Pomc probe (corresponding to base 532-1000 of GenBank sequence NM_008895.3) was denatured at $85^{\circ} \mathrm{C}$ for $5 \mathrm{~min}$ and then added at $200 \mathrm{pg} / \mu \mathrm{l}$, along with $0.5 \mathrm{mg} / \mathrm{ml}$ tRNA and $10 \mathrm{~mm}$ DTT, to the hybridization buffer bathing the slices and allowed to hybridize at $70^{\circ} \mathrm{C}$ for $18-20 \mathrm{~h}$.

On day 2 following hybridization, slices were first washed at $60^{\circ} \mathrm{C}$ three times in solution containing $50 \%$ formamide and $5 \times \mathrm{SSC}$ followed by three washes at $60^{\circ} \mathrm{C}$ in $50 \%$ formamide and $2 \times$ SSC. Slices were then digested for $30 \mathrm{~min}$ at $37^{\circ} \mathrm{C}$ with RNase A [ $20 \mu \mathrm{g} / \mathrm{ml}$ in $0.5 \mathrm{M}$ $\mathrm{NaCl}, 10 \mathrm{~mm}$ Tris- $\mathrm{HCl}(\mathrm{pH}$ 8.0), and $1 \mathrm{~mm}$ EDTA] and washed three times for $15 \mathrm{~min}$ at room temperature in TNT $[0.1 \mathrm{~m}$ Tris- $\mathrm{HCl}(\mathrm{pH} 7.5), 0.15 \mathrm{~m} \mathrm{NaCl}$, and $0.05 \%$ Tween 20]. Slices were blocked for $1 \mathrm{~h}$ in TNB (TNT plus $0.5 \%$ blocking reagent provided in the TSA kit; PerkinElmer) and then incubated overnight at $4^{\circ} \mathrm{C}$ in sheep anti-FITC (1:1000; Roche Applied Sciences) antibody conjugated to horseradish peroxidase.

On day 3, probe was detected using a TSA PLUS DNP (HRP) system (PerkinElmer). Slices were then washed for $15 \mathrm{~min}$ three times in TNT and then incubated for $30 \mathrm{~min}$ in a 1:50 dilution of DNP Amplification reagent. Slices were then washed in TNT and exposed to 1:400 rabbit antiDNP-KLH conjugated to Alexa Fluor 488 (1 h; Invitrogen) in TNT. Tissue was mounted in Aqua Poly/Mount (Polysciences).

\section{FISH imaging and analysis}

Images were collected using an LSM 800 Airyscan confocal microscope (Zeiss) using Zen Blue software (Zeiss). Stacks of images (six to eight slices per stack) were collected for each slice at an interval of $3 \mu \mathrm{m}$ through the entire rostral-caudal extent of the arcuate nucleus. All images were collected with the same laser power and digital gain. All analyses were performed using Fiji (ImageJ) software. To control for probe penetration, top and bottom stack images were eliminated before stack merging via max intensity projection followed by intensity-based thresholding. This created a mask for analysis, which then allowed fluorescence intensity of each cell within the stack to be measured. Fluorescence intensity values were subtracted by a representative sampling of the background intensity to control for variability of staining between slices. An average intensity was calculated for each brain from the fluorescent intensities of all analyzed cells.

\section{Radioimmunoassay}

At time of tissue collection, serum samples were collected from trunk blood and stored at $-80^{\circ} \mathrm{C}$ until measurements were made. $\beta$-Endorphin levels in plasma were determined using a commercial radioimmunoassay kit according to the manufacturer's instructions (RK-022-33, Phoenix Pharmaceuticals). In brief, samples were incubated overnight at $4^{\circ} \mathrm{C}$ with rabbit anti- $\beta$-endorphin, followed by another overnight incubation with ${ }^{125}$ I- 
$\beta$-endorphin. Samples were then incubated with goatanti-rabbit IgG serum and normal rabbit serum, centrifuged, and the supernatant discarded before detection of bound ${ }^{125} \mid-\beta$-endorphin in the remaining pellet with a $\gamma$-counter (PerkinElmer). A standard curve was generated from which the concentration of $\beta$-endorphin present in each sample was extrapolated.

\section{Statistics}

Results for male and female mice were examined separately for each experiment and were not statistically different. Therefore, all datasets pooled to include both male and female mice. Normality tests were performed on all datasets using the Royston (Royston 1995) method of the Shapiro-Wilk normality test. Normal datasets were analyzed using unpaired $t$ tests, and non-normal datasets were analyzed using Mann-Whitney $t$ tests where indicated. ME-induced dose-response curves were compared by nonlinear regression and sum-of-squares $F$ test to compare $\mathrm{EC}_{50}$. All data are presented as mean $\pm \mathrm{SD}$. Dose $\times$ time responses to LDN were analyzed by twoway ANOVA with Tukey's multiple comparison test performed in the case of a statistically significant interaction.

\section{Results}

\section{Treatment with LDN does not alter ME-induced outward currents}

To determine whether LDN might produce its beneficial effects by increasing the sensitivity of opioid receptors on POMC neurons, we examined responses to the opioid receptor agonist ME in slices from mice treated with LDN or vehicle. Mice were injected daily with either $0.1 \mathrm{mg} / \mathrm{kg}$ naltrexone in $0.1 \mathrm{ml}$ saline or $0.1 \mathrm{ml}$ saline intraperitonially for one week. This treatment plan was selected as animal studies suggest that this dosage and time period is enough to elicit peripheral effects of LDN (Van Bockstaele et al., 2006; Hammer et al., 2016; Ludwig et al., 2017). On day $7,2 \mathrm{~h}$ after the final LDN injection, brains were extracted and whole cell patch-clamp recordings were made from POMC neurons in slices containing the ARH. ME application induced an outward current, which on POMC neurons has been shown to be mediated largely by MORs coupled to inwardly rectifying potassium channels (GIRKs; Fig. 1A; Pennock and Hentges, 2011; Fox and Hentges, 2017). If LDN conferred an increased sensitivity to opioids, ME application would be expected to increase the amplitude of the outward current. However, treatment with LDN did not alter the dose response of the $\mathrm{ME}-$ induced peak outward current $\left(\mathrm{EC}_{50}\right.$ saline $=1.315$, $\mathrm{EC}_{50} \mathrm{LDN}=1.071, F_{(1,67)}=0.033, p=0.855$; Fig. $\left.1 B\right)$. Therefore, LDN does not appear to confer enhanced sensitivity or coupling of opioid receptors on POMC neurons to GIRKs.

\section{Treatment with LDN does not alter ME-induced inhibition of SPSCs}

sPSCs, mediated by inputs to POMC neurons, are inhibited by the activation of opioid receptors on presynaptic terminals and show a greater sensitivity to opioid
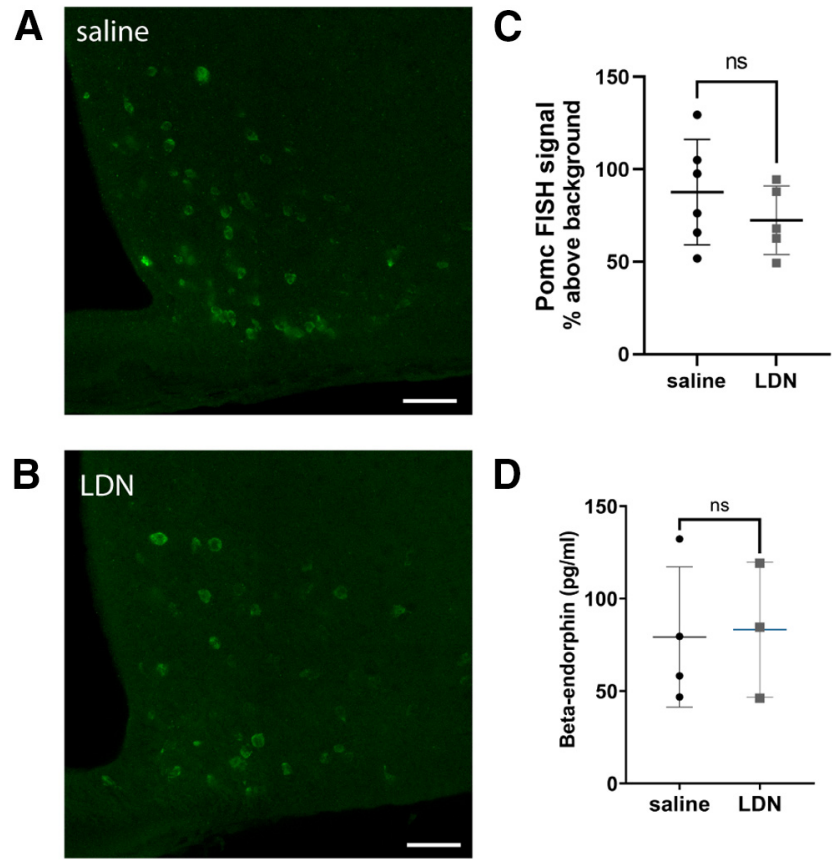

Figure 2. Treatment with LDN did not alter mRNA production of Pomc in the arcuate nucleus or release of $\beta$-endorphin into plasma. $\boldsymbol{A}$, Representative FISH image from the medial arcuate nucleus in animal treated with saline and $(\boldsymbol{B})$ LDN. Scale bars: $50 \mu \mathrm{m}$. C, No significant difference was observed in Pomc FISH intensity between animals treated with saline or LDN. Data points are average intensities of all cells in one brain (saline cell count per brain $=1008 \pm 314.7$, LDN cell count per brain= $578.8 \pm 211.5)$. $\boldsymbol{D}$, No change in $\beta$-endorphin concentrations in blood plasma was observed after LDN treatment. Each data point represents the average of individual cell fluorescence from one mouse. ns, not significant.

agonist application than outward currents (Pennock and Hentges, 2011). Therefore, we also determined how sPSCs were affected by ME application in LDN-treated and saline-treated mice. Because opioid agonists do not appear to preferentially suppress inhibitory or excitatory inputs (Pennock and Hentges, 2011), both EPSCs and IPSCs were examined at once. As shown in Figure $1 C, D$, no significant change was observed between LDNtreated and saline-treated groups in the inhibition of sPSCs onto POMC neurons in response to ME application $\left(E_{50}\right.$ saline $=0.30, E_{50} \mathrm{LDN}=0.10 ; F_{(1,59)}=1.219$, $p=0.274)$. Therefore, LDN treatment does not appear to alter the sensitivity of opioid receptor inhibition of transmitter release in neurons upstream of POMC neurons.

\section{Expression of POMC mRNA and release of $\beta$-endorphin peptide}

Finding no evidence for overt changes in presynaptic or postsynaptic sensitivity of MORs, we explored the possibility that LDN may alter the production or release of endogenous opioids to mediate the reported efficacy of the treatment. Previous studies have shown that high-dose naltrexone treatment can alter production of POMC peptides relevant to analgesia (Markowitz et al., 1992; 
Table 1. Basal properties of POMC neurons in slices from mice treated for $7 \mathrm{~d}$ with LDN or saline

\begin{tabular}{llllllll}
\hline & $\begin{array}{l}\text { Resting membrane } \\
\text { potential }(\mathrm{mV})\end{array}$ & $\begin{array}{l}\text { Membrane } \\
\text { capacitance }(\mathrm{pF})\end{array}$ & $\begin{array}{l}\text { Input resistance } \\
(\mathrm{M} \Omega)\end{array}$ & $\begin{array}{l}\text { sPSC } \\
\text { frequency }(\mathrm{Hz})\end{array}$ & $\begin{array}{l}\text { sPSC } \\
\text { amplitude }(\mathrm{pA})\end{array}$ & $\begin{array}{l}\text { AP threshold } \\
(\mathrm{mV})\end{array}$ & $\begin{array}{l}\text { AP frequency } \\
(\mathrm{Hz})\end{array}$ \\
\hline Saline & $-39.44 \pm 6.33$ & $23.65 \pm 7.72$ & $820.8 \pm 737.1$ & $8.789 \pm 4.30$ & $59.86 \pm 31.73$ & $-38.98 \pm 5.78$ & $7.13 \pm 4.08$ \\
mean $\pm \mathrm{SD}$ & $n=10$ & $n=32$ & $n=32$ & $n=33$ & $n=33$ & $n=11$ \\
$\mathrm{LDN}$ & $-41.39 \pm 11.30$ & $19.38 \pm 6.12$ & $743.7 \pm 699.1$ & $6.185 \pm 4.16$ & $42.82 \pm 23.64$ & $-41.89 \pm 6.25$ & $5.24 \pm 5.76$ \\
mean $\pm \mathrm{SD}$ & $n=11$ & $n=34$ & $n=34$ & $n=32$ & $n=31$ & $n=12$ & $n=11$ \\
$p$ & 0.6355 & 0.0151 & 0.6642 & 0.0160 & 0.0183 & 0.2606 \\
$t(\mathrm{df})$ & $0.4818(19)$ & $2.498(64)$ & $0.4362(64)$ & $2.475(63)$ & $2.424(62)$ & 0.4190 \\
& & & & & & & \\
\end{tabular}

Membrane capacitance, sPSC frequency, and sPSC amplitude were all lower in the LDN group as compared with saline ( $p>0.05)$. Values are expressed as mean $\pm \mathrm{SD}$; $n$ represents cell numbers. Total slices for each group: (columns $2-5$ ) same as cell numbers, (columns $1,6,7)$ saline $=10$, LDN $=9$. Total mice for each group: (columns $2-5$ ) saline $=21$, $L D N=19$; (columns $1,6,7)$ saline $=5$, $L D N=4$.

Panigrahi et al., 2019). To begin to explore whether LDN may alter the release of the opioid $\beta$-endorphin from POMC neurons, we first examined the expression of Pomc mRNA as this is the transcriptional precursor to the prohormone from which $\beta$-endorphin is cleaved. Pomc mRNA was detected using fluorescent FISH in tissue from LDN-treated and vehicle-treated animals. Fluorescence intensity of the Pomc FISH signal was determined and reported relative to background fluorescence with all tissue processed and imaged under identical conditions (Fig. $2 A-C)$. We found no difference in signal intensity in cells from the two treatments (vehicle vs LDN; $t_{(9)}=1.023$, $p=0.3329$ ).

While Pomc FISH provides an indication of relative mRNA production and potential peptide changes centrally, it is possible that release into plasma is selectively altered by LDN treatment. Therefore, we also examined whether LDN treatment altered the presence of $\beta$-endorphin in the plasma of treated animals (Fig. 2D). However, no difference was observed in plasma concentration of $\beta$-endorphin between LDN-treated and saline-treated animals (saline $=79.17 \pm 37.88$, LDN $=83.24 \pm 36.52 \mathrm{pg} / \mathrm{ml}$, $\left.t_{(5)}=0.143, p=0.892\right)$. Therefore, LDN treatment does not appear to alter Pomc mRNA production in the ARH nor release of $\beta$-endorphin into blood plasma.

\section{Baseline characteristics of POMC neurons in animals treated with LDN or saline}

Despite the lack of noted effects thus far in the studies, we could not rule the possibility that LDN might change the activity of POMC neurons and perhaps peptide release centrally. In fact, during baseline recording for opioid dose-response experiments, it was observed that while opioid responses did not differ, some intrinsic properties of POMC neurons were different in tissue from LDN-treated mice. Intrinsic properties and statistics of POMC neurons from animals treated with LDN or saline are shown in Table 1. POMC neurons from animals treated with LDN had a slightly smaller capacitance than POMC neurons from animals treated with saline and exhibited SPSCs with lower amplitudes and frequency than POMC neurons in the saline group. Recordings from a subset of LDN-treated and salinetreated mice confirmed that the frequency of IPSCs (saline $=7.35 \pm 4.97, \mathrm{LDN}=5.08 \pm 4.20$ ) was higher than the frequency of EPSCs (saline $=1.83 \pm 1.48, \mathrm{LDN}=1.37 \pm 1.47$ ) in both groups, confirming previous studies showing that the majority of SPCSs in POMC neurons are mediated by presynaptically-released GABA (Pinto et al., 2004; Hentges et al., 2009). Therefore, it may be that LDN decreases inhibitory tone onto POMC neurons.

\section{GCaMP-derived calcium responses in POMC neurons are altered by ME}

To determine whether the LDN-induced decrease in sPSCs in POMC neurons leads to enhanced POMC neuron activity, we first examined signal indicative of calcium level and flux in POMC neurons from mice treated with LDN or saline as a proxy for POMC neuron activity. GCaMP fluorescence reporter imaging was chosen as a starting point, as this assay has been reported to be a very sensitive indicator of altered POMC neuron activity (Fox and Hentges, 2017) and generally correlates with depolarization and firing rate changes (Jayaraman and Laurent, 2007; Hartung and Gold, 2020). For calcium-dependent GCaMP imaging, AAV containing a floxed sequence for GCaMP6f was delivered into the arcuate nucleus of $P \mathrm{OmC}^{\mathrm{Cre} /+}$ mice and $7 \mathrm{~d}$ of LDN administration was completed. GCaMP-derived calcium signal was recorded and normalized to the loss of calcium signal induced by $10 \mu \mathrm{M}$ ME application after baseline signal recording was completed. This normalization was chosen because of the reliable ME response in cells and because electrophysiological experiments showed no difference in opioid responsiveness between cells in slices from LDNtreated or saline-treated mice. All neurons that appeared healthy and responded to $10 \mu \mathrm{M}$ ME were included, and baseline calcium fluorescence was analyzed as area under the curve after normalization to ME. POMC neurons from animals treated with LDN showed greater calcium signal at baseline compared with POMC neurons from animals treated with saline (Mann-Whitney $U=1=86, n_{\text {sal }}=$ $22 n_{\text {LDN }}=15, p=0.0138$; Fig. 3). Therefore, LDN treatment may generally enhance excitability as suggested by the increase in GCaMP-derived calcium signal.

\section{Intrinsic excitability of POMC neurons}

To test whether an increase in GCaMP-based calcium activity was indeed accompanied by an increase in POMC neuron intrinsic excitability, action potential thresholds were determined for POMC neurons from animals treated with LDN and saline (see Table 1). Neither resting membrane potential frequency of action 


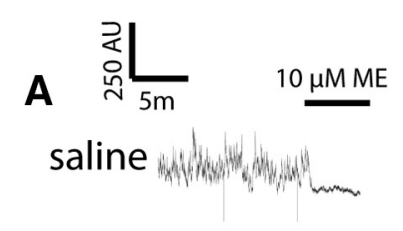

B

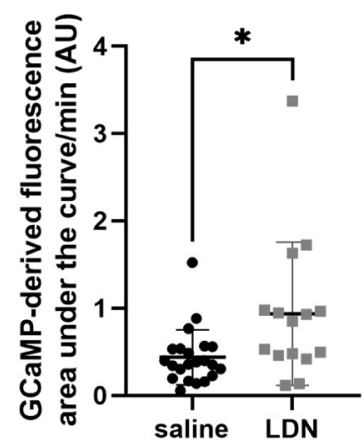

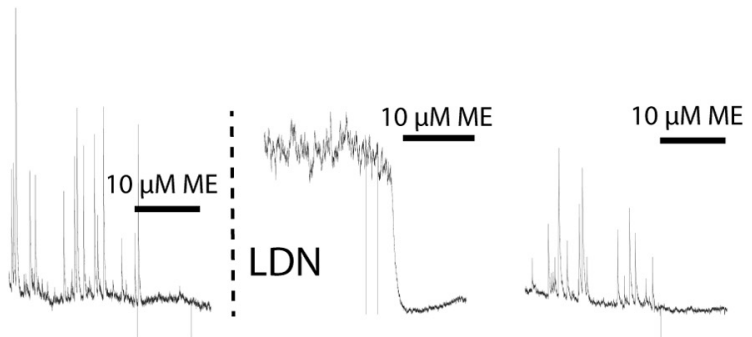

C

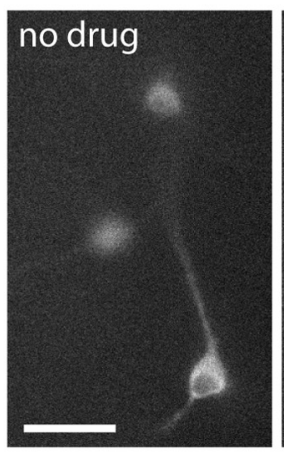

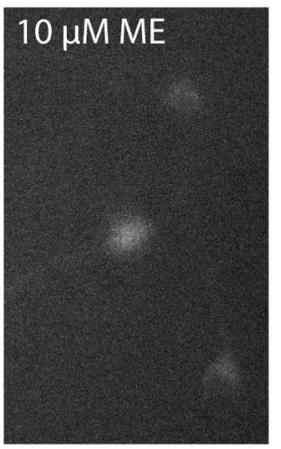

Figure 3. Treatment with LDN slightly increased baseline GCaMP calcium indicator-derived fluorescence. $\boldsymbol{A}$, Baseline GCaMP-derived fluorescence and fluorescence after $10 \mu \mathrm{M}$ ME treatment from cells of animals treated with saline or LDN. $\boldsymbol{B}$, Baseline fluorescence normalized to $10 \mu \mathrm{M}$ ME application differed significantly between saline and LDN groups; ${ }^{*} p<0.05$. Each data point represents one cell. Total slices for each group: saline $=10, \mathrm{LDN}=8$. Total mice for each group: $\operatorname{saline}=5, \mathrm{LDN}=5$. $\boldsymbol{C}$, Example image of GCaMP expressing POMC neurons before and after treatment with $10 \mu \mathrm{M}$ ME. Scale bar: $50 \mu \mathrm{m}$.

A
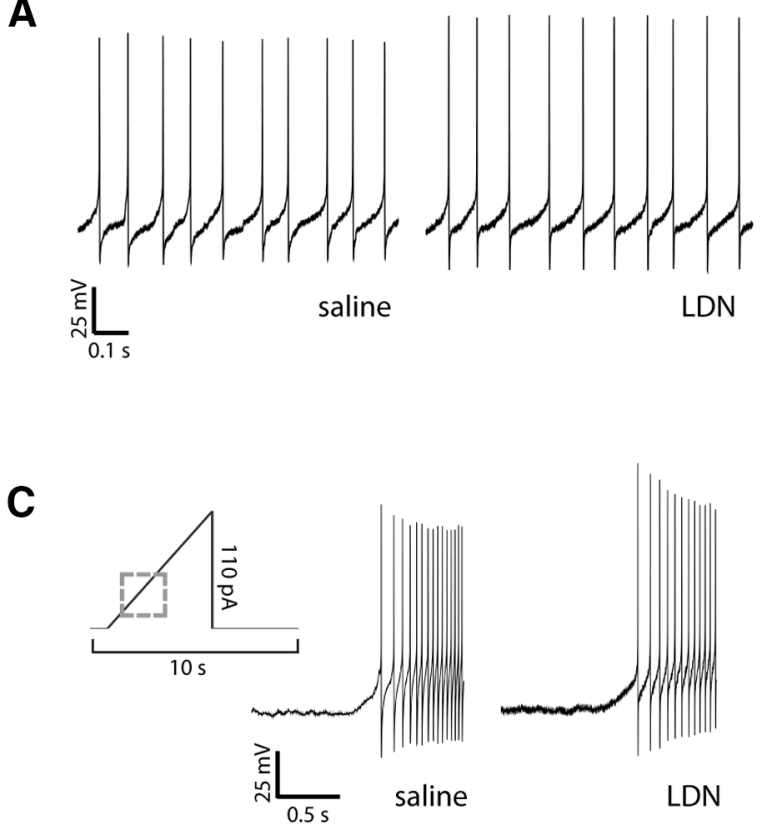

B

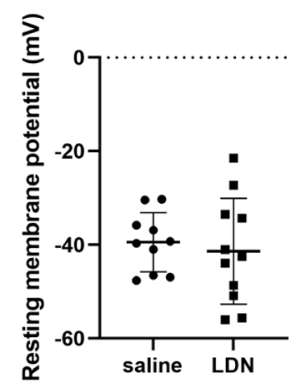

D

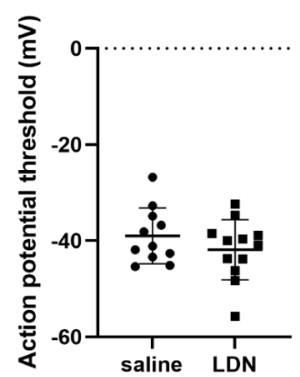

Figure 4. Treatment with LDN did not alter intrinsic excitability of POMC neurons. $\boldsymbol{A}$, Example current clamp recordings from POMC neurons of saline-treated and LDN-treated mice. B, Resting membrane potential did not differ between POMC neurons from animals treated with saline and LDN. $\boldsymbol{C}$, Representation of ramp used to determine action potential threshold. The threshold ramp was $5 \mathrm{~s}$ and ramped from 0 to $110 \mathrm{pA}$ with a 1-s delay preramp. Dashed gray box represents location of saline and LDN representative traces during action potential ramp. Example traces from saline-treated and LDN-treated cells are shown from the beginning of the ramp protocol, with action potentials beginning $0.3 \mathrm{~s}$ after initiation of the ramp. $\boldsymbol{D}$. Action potential threshold did not differ between POMC neurons from animals treated with saline and LDN. Each data point represents one cell. Total slices used for each group (from a total of saline $=5$ and $\operatorname{LDN}=4$ mice per group): saline $=10, \mathrm{LDN}=9$. 
Table 2. Baseline properties of POMC neurons from animals treated with varied doses and times of LDN

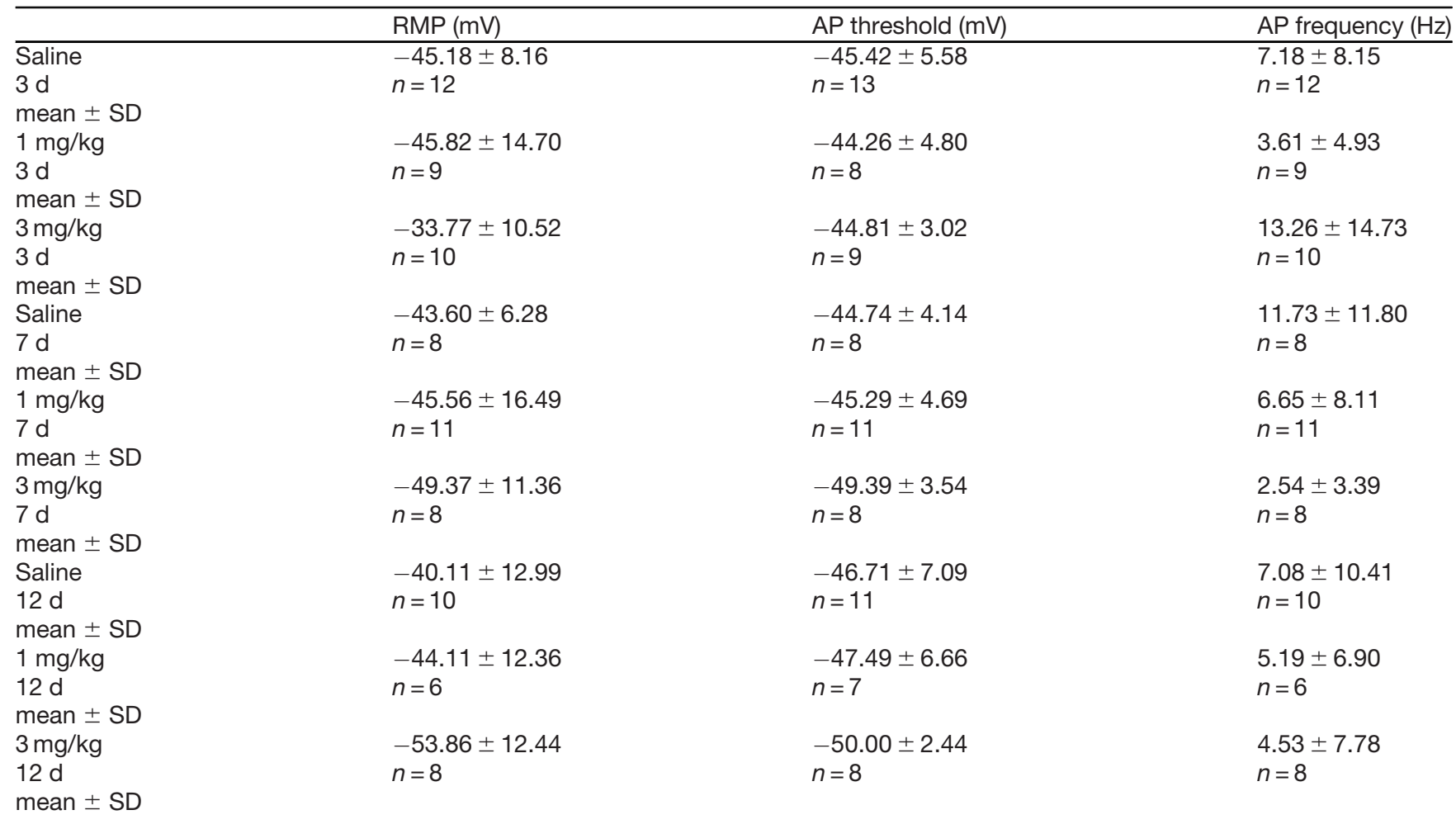

Resting membrane potential, action potential threshold, and action potential frequency mean \pm SD are presented for cells from slices taken from mice treated with saline, 0.1 or $3 \mathrm{mg} / \mathrm{kg}$ LDN for 3,7 , or $12 \mathrm{~d}$. No main effects were detected for any parameter. $n=$ number of cells recorded from and comes from 2 or more slices from at least three mice.

potentials was different between groups (Fig. 4). Action potential threshold was measured in the presence of presynaptic blockers for $\mathrm{GABA}_{\mathrm{A}}$ receptors (Bicuculline methiodide, 10 $\mu \mathrm{M})$, AMPA receptors (DNQX, $10 \mu \mathrm{M}$ ), and NMDA receptors (MK-801, $15 \mu \mathrm{M})$. Action potentials were elicited with a 0 - to 110-pA current ramp. The amount of current required to elicit an action potential from a holding potential of $-60 \mathrm{mV}$ did not differ between groups (saline $=33.63 \pm 21.69 \mathrm{pA}$, LDN = $30.09 \pm 23.86 \mathrm{pA}, t_{(17)}=0.3215, p=0.7518$; Fig. $\left.4 C, D\right)$. Therefore, LDN treatment does not appear to alter baseline firing nor intrinsic excitability of POMC neurons.

\section{Dose $\times$ time response of POMC neuron intrinsic excitability and $\beta$-endorphin release}

While the above experiments indicate that $7 \mathrm{~d}$ of $0.1 \mathrm{mg} / \mathrm{kg}$ LDN does not appear to change $\beta$-endorphin release into plasma or POMC neuron intrinsic excitability, it is possible that LDN effects on the $\beta$-endorphin system could be short-lasting or take longer than $7 \mathrm{~d}$ to manifest. Therefore, we examined these parameters after 3, 7, and $12 \mathrm{~d}$ of LDN exposure at 0.1 and $3 \mathrm{mg} / \mathrm{kg}$ LDN compared with saline controls (Table 2). No main effects of dose $\left(F_{(2,73)}=0.39, p=0.68\right)$, nor time $\left(F_{(2,73)}=1.31, p=0.28\right)$ were apparent for resting membrane potential (Fig. $5 A$ ). Similarly, action potential threshold did not appear to be altered by dose $\left(F_{(2,74)}=2.82, p=0.60\right)$ or time $\left(F_{(2,74)}=\right.$ 2.02, $p=0.14$; Fig. $5 B$ ), and action potential frequency also showed no main effects of dose $\left(F_{(2,73)}=0.45\right.$, $p=0.64)$ or time $\left(F_{(2,73)}=0.97, p=0.38\right.$; Fig. $\left.5 C\right)$. $\beta$-endorphin concentrations in plasma were also measured after the dose $\times$ time experiment and there were no main effects (dose: $F_{(2,32)}=0.62, p=0.54$; time: $F_{(2,32)}=2.23$, $p=0.12)$, but an interaction was observed between groups $\left(F_{(4,32)}=2.95, p=0.04\right)$ with the concentration of $\beta$-endorphin being slightly lower in the $0.1 \mathrm{mg} / \mathrm{kg}$ group compared with the saline group at $3 d(p=0.02$; Fig. $5 D)$. No other groups were significantly different in their plasma $\beta$-endorphin concentrations within any of the treatment time blocks.

\section{Discussion}

Overall, LDN appears to have minimal effects on the activity of POMC neurons. The amplitude and frequency of PSCs onto POMC neurons was slightly decreased, and GCaMP-derived calcium signal from POMC neurons was increased. However, the resting membrane potential, firing frequency, and intrinsic excitability of POMC neurons were all unaltered by LDN, even when dosage and time of treatment was altered. Consistent with this, LDN treatment did not consistently change the production of Pomc mRNA or the release of $\beta$-endorphin into blood plasma. Thus, we found no evidence to support the hypothesis that LDN may exert its reported mood enhancing and pain reducing actions by stimulating the endogenous $\beta$-endorphin system.

It has repeatedly been shown that high doses of naltrexone increase MOR expression throughout the brain (Tempel et al., 1984; Unterwald et al., 1995, 1998; Díaz et 
A

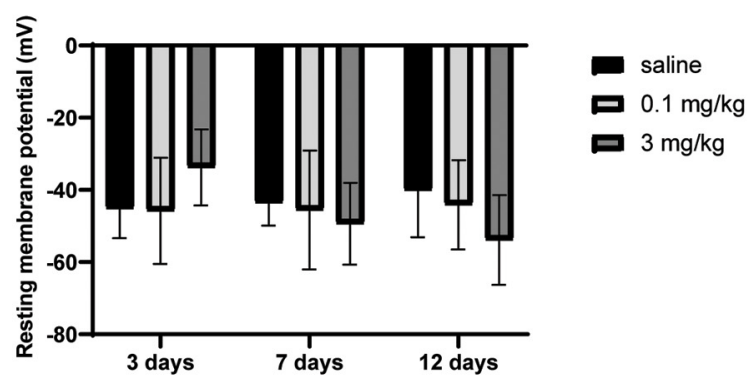

B

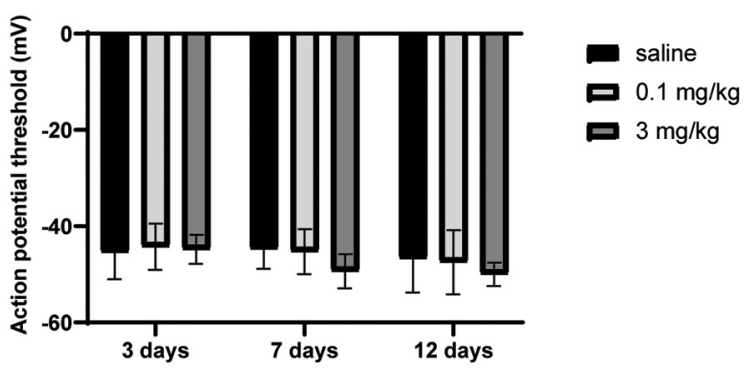

C

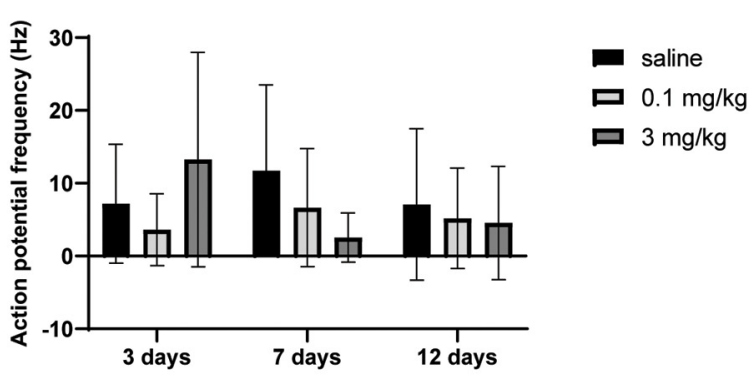

D

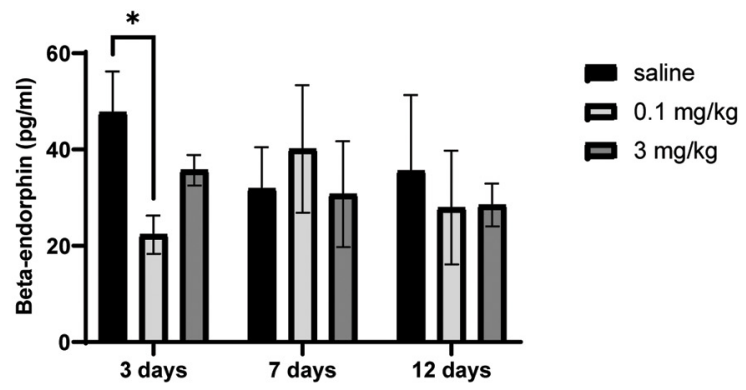

Figure 5. Increased dose of LDN or varied the time of LDN exposure did not cause sustained changes in POMC neuron intrinsic excitability or $\beta$-endorphin plasma concentrations. $\boldsymbol{A}$, Resting membrane potential did not change after 3-, 7-, or 12-d LDN treatment at either 0.1 or $3 \mathrm{mg} / \mathrm{kg}$. B, Varying the time or dose of LDN treatment also did not change POMC neuron action potential threshold or (C) action potential frequency. $\boldsymbol{D}$, LDN treatment did not systematically alter $\beta$-endorphin concentrations in plasma, although a transient decrease in $\beta$-endorphin concentration was observed with $0.1 \mathrm{mg} / \mathrm{kg}$ at $3 \mathrm{~d}$ of treatment. Number of mice used for each group in the $\beta$-endorphin group are as follows: $3 \mathrm{~d}$ saline $=3,0.1 \mathrm{mg} / \mathrm{kg} \operatorname{LDN}=3$, $3 \mathrm{mg} / \mathrm{kg} L D N=4 ; 7 \mathrm{~d}$ saline $=7,7 \mathrm{~d} 0.1 \mathrm{mg} / \mathrm{kg}=8,7 \mathrm{~d} 3 \mathrm{mg} / \mathrm{kg}=4$; $12 \mathrm{~d}$ saline $=5,12 \mathrm{~d} 0.1 \mathrm{mg} / \mathrm{kg} \operatorname{LDN}=4,12 \mathrm{~d} 3 \mathrm{mg} / \mathrm{kg}=4 ;{ }^{*} p<0.05$. al., 2002). Further, studies examining behavioral effects show enhanced respiratory depression and analgesia after extended high-dose naltrexone followed by acute agonist administration (Díaz et al., 2002); therefore, it appears these upregulated opioid receptors are functional. However, our studies indicate that LDN does not increase coupling to effectors in POMC neurons, and likely does not induce increased expression, unless there are extra non-signaling receptors. Thus, LDN does not appear to have the same effect as higher, more chronic doses of naltrexone in vivo on opioid receptors in POMC neurons.

The lack of consequences found in the current study do not rule out that LDN could be affecting opioid receptor function in other brain regions. Opioid receptor expression is widespread throughout the central nervous system (Le Merrer et al., 2009; Corder et al., 2018), and some regions may be more sensitive to antagonist-induced changes than POMC neurons. While long-term analgesic effects of LDN are speculated to occur peripherally, it is known that top-down activation is important for pain relief. The central analgesic system contains the periaqueductal gray (PAG), which sends inhibitory projections to the rostral ventromedial medulla (RVM), and both of these brain regions are known to express opioid receptors, which could be affected by LDN (Gutstein et al., 1998). Further, effects on mood and dreaming reported by many patients taking LDN likely have a central mechanism, and several brain regions involved in affecting mood, including parts of the limbic system, express opioid receptors (George et al., 1994; Zubieta et al., 2003). Thus, LDN could affect opioid receptor systems in these regions to account for alterations to mood previously reported by patients.

Investigation of central $\beta$-endorphin expression and release in response to LDN also revealed little change. Changes in endogenous $\beta$-endorphin tone after LDN were hypothesized to occur because $\beta$-endorphin is known to improve affect and thus could account for improvements in mood reported by patients taking LDN. Further, previous studies administering high-dose naltrexone show increases in $\beta$-endorphin and POMC peptide expression in plasma and brain (Nikolarakis et al., 1987; Markowitz et al., 1992; Jaffe et al., 1994; Gordon et al., 2017; Panigrahi et al., 2019). Therefore, we examined the effect of LDN on Pomc transcript and $\beta$-endorphin in plasma. It is worth commenting on the different $y$-axis scale bars referring to $\beta$-endorphin concentrations in Figure 2 versus Figure 5 . The samples shown in Figure 5 were analyzed using reagents with different production lot numbers as those used in Figure 2 and this likely explains the difference observed in absolute concentration. Within each experiment, it is clear no difference in plasma $\beta$-endorphin levels is observed whether animals receive saline or one of two doses of LDN except that only $0.1 \mathrm{mg} / \mathrm{kg}$ LDN treatment for $3 \mathrm{~d}$, may have slightly decreased $\beta$-endorphin concentration in plasma. This was in the opposite direction of our hypothesized increase in $\beta$-endorphin but could be indicative of an earlier release event followed by a dip in plasma peptide concentration. However, if anything, this change is transient and seems to resolve by 
$7 \mathrm{~d}$, therefore it is unlikely to explain the reported efficacy of LDN that may last for months or years (Ludwig et al., 2016).

It is also plausible that LDN could have effects on other opioid peptide systems in the brain. POMC neurons of the $\mathrm{ARH}$ are the most prominent source of $\beta$-endorphin in the brain (Zakarian and Smyth, 1982). However, other opioid peptides, such as enkephalins and dynorphins, are also known to affect anxiety, aversion, and stress, all of which could be related to mood changes reported by patients using LDN (Wittmann et al., 2009; Femenía et al., 2011; Ménard et al., 2013; Melo et al., 2014; Nam et al., 2019). The production of precursors for enkephalin and endorphin are much more widespread in the brain than the production of the precursor polypeptide POMC (Le Merrer et al., 2009; Corder et al., 2018), and thus the ease in detecting changes in these systems would likely depend on how generalized the alterations in the production of those specific peptides are, if present at all. Peripherally, LDN does appear to induce increases in the level of met-enkephalin in patients with multiple sclerosis (Ludwig et al., 2017), therefore changes in central enkephalin systems may also be possible. Further, many previous studies use LDN treatments for populations in which opioid systems may already be dysfunctional, and LDN may be acting to reset this system back to normal. Because our studies were in healthy animals, we cannot rule out the possibility that LDN could confer effects in conditions of pathologic opioid system function.

Overall, our lack of LDN-induced changes within POMC neurons does not rule out changes in animals with dysfunctional opioid tone, changes with longer term LDN treatment, or changes within the rest of the brain. Understanding the central effects of LDN is important, not only from the perspective of basic science, but also to inform future applications of LDN, as LDN is already being explored as a potential treatment for depression (Mischoulon et al., 2017). From our studies, it appears that future inquiries would be best served by focusing on opioid systems other than the central $\beta$-endorphin system or by examining the effects of LDN in conditions where dysfunctions in $\beta$-endorphin tone likely exist.

\section{References}

Bolton MJ, Chapman BP, Van Marwijk H (2020) Low-dose naltrexone as a treatment for chronic fatigue syndrome. BMJ Case Rep 13: e232502.

Brewer KL, Mainhart A, Meggs WJ (2018) Double-blinded placebocontrolled cross-over pilot trial of naltrexone to treat gulf war illness. Fatigue 6:132-140.

Burns LH, Wang HY (2010) PTI-609: a novel analgesic that binds filamin A to control opioid signaling. Recent Pat CNS Drug Discov 5:210-220.

Chopra P, Cooper MS (2013) Treatment of complex regional pain syndrome (CRPS) using low dose naltrexone (LDN). J Neuroimmune Pharmacol 8:470-476.

Corder G, Castro DC, Bruchas MR, Scherrer G (2018) Endogenous and exogenous opioids in pain. Annu Rev Neurosci 41:453-473.

Council NR (2011) Guide for the care and use of laboratory animals, Ed 8. Washington, DC: The National Academies Press.

Díaz A, Pazos A, Flórez J, Ayesta FJ, Santana V, Hurlé MA (2002) Regulation of mu-opioid receptors, G-protein-coupled receptor kinases and beta-arrestin 2 in the rat brain after chronic opioid receptor antagonism. Neuroscience 112:345-353.

Femenía T, Pérez-Rial S, Urigüen L, Manzanares J (2011) Prodynorphin gene deletion increased anxiety-like behaviours, impaired the anxiolytic effect of bromazepam and altered GABAA receptor subunits gene expression in the amygdala. J Psychopharmacol 25:87-96.

Fox PD, Hentges ST (2017) Differential desensitization observed at multiple effectors of somatic $\mu$-opioid receptors underlies sustained agonist-mediated inhibition of proopiomelanocortin neuron activity. J Neurosci 37:8667-8677.

George SR, Zastawny RL, Briones-Urbina R, Cheng R, Nguyen T, Heiber M, Kouvelas A, Chan AS, O'Dowd BF (1994) Distinct distributions of mu, delta and kappa opioid receptor mRNA in rat brain. Biochem Biophys Res Commun 205:1438-1444.

Ghai B, Bansal D, Hota D, Shah CS (2014) Off-label, low-dose naltrexone for refractory chronic low back pain. Pain Med 15:883884.

Gold MS, Dackis CA, Pottash AL, Sternbach HH, Annitto WJ, Martin D, Dackis MP (1982) Naltrexone, opiate addiction, and endorphins. Med Res Rev 2:211-246.

Gordon RJ, Panigrahi SK, Meece K, Atalayer D, Smiley R, Wardlaw SL (2017) Effects of opioid antagonism on cerebrospinal fluid melanocortin peptides and cortisol levels in humans. J Endocr Soc 1:1235-1246.

Gutstein HB, Mansour A, Watson SJ, Akil H, Fields HL (1998) Mu and kappa opioid receptors in periaqueductal gray and rostral ventromedial medulla. Neuroreport 9:1777-1781.

Hammer LA, Waldner H, Zagon IS, McLaughlin PJ (2016) Opioid growth factor and low-dose naltrexone impair central nervous system infiltration by CD4 + T lymphocytes in established experimental autoimmune encephalomyelitis, a model of multiple sclerosis. Exp Biol Med (Maywood) 241:71-78.

Hartung JE, Gold MS (2020) GCaMP as an indirect measure of electrical activity in rat trigeminal ganglion neurons. Cell Calcium 89:102225.

Hayward MD, Pintar JE, Low MJ (2002) Selective reward deficit in mice lacking $\beta$-endorphin and enkephalin. J Neurosci 22:82518258.

Hentges ST, Otero-Corchon V, Pennock RL, King CM, Low MJ (2009) Proopiomelanocortin expression in both GABA and glutamate neurons. J Neurosci 29:13684-13690.

Jaffe SB, Sobieszczyk S, Wardlaw SL (1994) Effect of opioid antagonism on beta-endorphin processing and proopiomelanocortinpeptide release in the hypothalamus. Brain Res 648:24-31.

Jayaraman V, Laurent G (2007) Evaluating a genetically encoded optical sensor of neural activity using electrophysiology in intact adult fruit flies. Front Neural Circuits 1:3.

Labuz D, Celik M, Zimmer A, Machelska H (2016) Distinct roles of exogenous opioid agonists and endogenous opioid peptides in the peripheral control of neuropathy-triggered heat pain. Sci Rep 6:32799.

Le Merrer J, Becker JA, Befort K, Kieffer BL (2009) Reward processing by the opioid system in the brain. Physiol Rev 89:1379-1412.

Leonard JB, Nair V, Diaz CJ, Penoyar JB, Goode PA (2017) Potential drug interaction with opioid agonist in the setting of chronic lowdose opioid antagonist use. Am J Emerg Med 35:1209.e3-1209. e4.

Lie M, van der Giessen J, Fuhler GM, de Lima A, Peppelenbosch MP, van der Ent C, van der Woude CJ (2018) Low dose naltrexone for induction of remission in inflammatory bowel disease patients. J Transl Med 16:55.

Ludwig MD, Turel AP, Zagon IS, McLaughlin PJ (2016) Long-term treatment with low dose naltrexone maintains stable health in patients with multiple sclerosis. Mult Scler J Exp Transl Clin 2:2055217316672242.

Ludwig MD, Zagon IS, McLaughlin PJ (2017) Featured article: serum [Met(5)]-enkephalin levels are reduced in multiple sclerosis and restored by low-dose naltrexone. Exp Biol Med (Maywood) 242:1524-1533. 
Markowitz CE, Berkowitz KM, Jaffe SB, Wardlaw SL (1992) Effect of opioid receptor antagonism on proopiomelanocortin peptide levels and gene expression in the hypothalamus. Mol Cell Neurosci 3:184-190.

Matthes HW, Maldonado R, Simonin F, Valverde O, Slowe S, Kitchen I, Befort K, Dierich A, Le Meur M, Dollé P, Tzavara E, Hanoune J, Roques BP, Kieffer BL (1996) Loss of morphine-induced analgesia, reward effect and withdrawal symptoms in mice lacking the mu-opioid-receptor gene. Nature 383:819-823.

Melo I, Drews E, Zimmer A, Bilkei-Gorzo A (2014) Enkephalin knockout male mice are resistant to chronic mild stress. Genes Brain Behav 13:550-558.

Ménard C, Tse YC, Cavanagh C, Chabot J-G, Herzog H, Schwarzer C, Wong TP, Quirion R (2013) Knockdown of prodynorphin gene prevents cognitive decline, reduces anxiety, and rescues loss of group 1 metabotropic glutamate receptor function in aging. $J$ Neurosci 33:12792-12804.

Mischoulon D, Hylek L, Yeung AS, Clain AJ, Baer L, Cusin C, Ionescu DF, Alpert JE, Soskin DP, Fava M (2017) Randomized, proof-of-concept trial of low dose naltrexone for patients with breakthrough symptoms of major depressive disorder on antidepressants. J Affect Disord 208:6-14.

Misra AL, Bloch R, Vardy J, Mulé SJ, Verebely K (1976) Disposition of $(15,16-3 \mathrm{H})$ naltrexone in the central nervous system of the rat. Drug Metab Dispos 4:276-280.

Nam H, Chandra R, Francis TC, Dias C, Cheer JF, Lobo MK (2019) Reduced nucleus accumbens enkephalins underlie vulnerability to social defeat stress. Neuropsychopharmacology 44:1876-1885.

Nikolarakis KE, Almeida OF, Herz A (1987) Feedback inhibition of opioid peptide release in the hypothalamus of the rat. Neuroscience 23:143-148.

Panigrahi SK, Meece K, Wardlaw SL (2019) Effects of naltrexone on energy balance and hypothalamic melanocortin peptides in male mice fed a high-fat diet. J Endocr Soc 3:590-601.

Parikh D, Hamid A, Friedman TC, Nguyen K, Tseng A, Marquez P, Lutfy K (2011) Stress-induced analgesia and endogenous opioid peptides: the importance of stress duration. Eur J Pharmacol 650:563-567.

Patten DK, Schultz BG, Berlau DJ (2018) The safety and efficacy of low-dose naltrexone in the management of chronic pain and inflammation in multiple sclerosis, fibromyalgia, Crohn's disease, and other chronic pain disorders. Pharmacotherapy 38:382-389.

Pennock RL, Hentges ST (2011) Differential expression and sensitivity of presynaptic and postsynaptic opioid receptors regulating hypothalamic proopiomelanocortin neurons. J Neurosci 31:281-288.

Pinto S, Roseberry AG, Liu H, Diano S, Shanabrough M, Cai X, Friedman JM, Horvath TL (2004) Rapid rewiring of arcuate nucleus feeding circuits by leptin. Science 304:110-115.

Raknes G, Småbrekke L (2017) Low dose naltrexone in multiple sclerosis: effects on medication use. A quasi-experimental study. PLoS One 12:e0187423.

Raknes G, Småbrekke L (2019) Changes in the consumption of antiepileptics and psychotropic medicines after starting low dose naltrexone: a nation-wide register-based controlled before-after study. Sci Rep 9:15085.

Raknes G, Simonsen P, Småbrekke L (2018) The effect of low-dose naltrexone on medication in inflammatory bowel disease: a quasi experimental before-and-after prescription database study. J Crohns Colitis 12:677-686.

Ramanathan S, Panksepp J, Johnson B (2012) Is fibromyalgia an endocrine/endorphin deficit disorder? Is low dose naltrexone a new treatment option? Psychosomatics 53:591-594.

Raynor K, Kong H, Chen Y, Yasuda K, Yu L, Bell GI, Reisine T (1994) Pharmacological characterization of the cloned kappa-, delta-, and mu-opioid receptors. Mol Pharmacol 45:330-334.

Tempel A, Gardner EL, Zukin RS (1984) Visualization of opiate receptor upregulation by light microscopy autoradiography. Proc Natl Acad Sci USA 81:3893-3897.

Toljan K, Vrooman B (2018) Low-dose naltrexone (LDN)-review of therapeutic utilization. Med Sci 6:82

Trofimovitch D, Baumrucker SJ (2019) Pharmacology update: lowdose naltrexone as a possible nonopioid modality for some chronic, nonmalignant pain syndromes. Am J Hosp Palliat Care 36:907-912.

Unterwald EM, Rubenfeld JM, Imai Y, Wang JB, Uhl GR, Kreek MJ (1995) Chronic opioid antagonist administration upregulates mu opioid receptor binding without altering mu opioid receptor mRNA levels. Brain Res Mol Brain Res 33:351-355.

Unterwald EM, Anton B, To T, Lam H, Evans CJ (1998) Quantitative immunolocalization of mu opioid receptors: regulation by naltrexone. Neuroscience 85:897-905.

Van Bockstaele EJ, Rudoy C, Mannelli P, Oropeza V, Qian Y (2006) Elevated mu-opioid receptor expression in the nucleus of the solitary tract accompanies attenuated withdrawal signs after chronic low dose naltrexone in opiate-dependent rats. J Neurosci Res 83:508-514.

Veening JG, Gerrits PO, Barendregt HP (2012) Volume transmission of beta-endorphin via the cerebrospinal fluid; a review. Fluids Barriers CNS 9:16.

Wang HY, Burns LH (2009) Naloxone's pentapeptide binding site on filamin A blocks Mu opioid receptor-Gs coupling and CREB activation of acute morphine. PLoS One 4:e4282.

Wittmann W, Schunk E, Rosskothen I, Gaburro S, Singewald N, Herzog H, Schwarzer C (2009) Prodynorphin-derived peptides are critical modulators of anxiety and regulate neurochemistry and corticosterone. Neuropsychopharmacology 34:775-785.

Younger J, Mackey S (2009) Fibromyalgia symptoms are reduced by low-dose naltrexone: a pilot study. Pain Med 10:663-672.

Younger J, Noor N, McCue R, Mackey S (2013) Low-dose naltrexone for the treatment of fibromyalgia: findings of a small, randomized, double-blind, placebo-controlled, counterbalanced, crossover trial assessing daily pain levels. Arthritis Rheum 65:529-538.

Zagon IS, McLaughlin PJ (1983) Naltrexone modulates tumor response in mice with neuroblastoma. Science 221:671-673.

Zakarian S, Smyth DG (1982) $\beta$-Endorphin is processed differently in specific regions of rat pituitary and brain. Nature 296:250-252.

Zappaterra M, Shouse E, Levine RL (2020) Low-dose naltrexone reduces symptoms in Stiff-Person syndrome. Med Hypotheses 137:109546.

Zubieta JK, Ketter TA, Bueller JA, Xu Y, Kilbourn MR, Young EA, Koeppe RA (2003) Regulation of human affective responses by anterior cingulate and limbic mu-opioid neurotransmission. Arch Gen Psychiatry 60:1145-1153. 